\title{
Cryopreservation of sea bass (Dicentrarchus labrax) spermatozoa in experimental and production simulating conditions
}

\author{
Christian Fauvel ${ }^{(1 *)}$, Marc Suquet ${ }^{(2)}$, Catherine Dreanno ${ }^{(2,3)}$, \\ Vincenzo Zonno ${ }^{(4)}$, Bruno Menu ${ }^{(1)}$
}

(1) Station expérimentale d'aquaculture, Ifremer, Chemin-de-Maguelone, 34250 Palavas-les-Flots, France.

(2) Laboratoire de physiologie des poissons, Ifremer, BP 70, 29280 Plouzané, France.

(3) Laboratoire d'ichtyologie appliquée, Muséum national d'histoire naturelle, 43, rue Cuvier, 75231 Paris cedex 05, France.

(4) Laboratorio di Fisiologia Generale, Dipartimento di Biologia, Universita de Lecce, Via Monteroni, 73100 Lecce, Italy.

Received May 14, 1998; accepted September 23, 1998.

\begin{abstract}
A sperm cryopreservation protocol adapted from turbol, was tested on sea bass using either $250-\mu \mathrm{L}$ straws or 1.5 -mL cryovials. A dilution to $1 / 3$ in Mounib's extender and a cooling rate of $-65^{\circ} \mathrm{C} \cdot \mathrm{min}^{-1}$ allowed frozen sperm to recover an initial motility similar to that of fresh sperm at thawing; however, significant differences in motility $(P<0.001, n=10$ fish semen) were observed at further post-activation times, the motility decrease being faster in thawed sperm. At the experimental scale, triplicate inseminations of 2-mL aliquots (approximately $2000 \mathrm{eggs}$ ) showed a significant fertility decay of thawed sperm compared to that of fresh sperm $\left(P<0.01, n=12\right.$ fish semen) when a discriminating $35 \cdot 10^{3}$ spermatozoa to egg ratio was applied. When $70 \cdot 10^{3}$ and $200 \cdot 10^{3}$ spermatozoa per egg were provided in the same experimental conditions, no significant difference appeared between the fertilisation rates of fresh and thawed sperm. In order to validate the procedure for production or cryobank purpose, a scaled-up protocol was established. Two and $50 \mathrm{~mL}$ batches of eggs (approximately $2 \cdot 10^{3}$ and $50 \cdot 10^{3}$ eggs, respectively) were inseminated in triplicate using either fresh or thawed individual sperms of 5 males with $200 \cdot 10^{3}$ spermatozoa per egg. The mean fertility decreased by $23.5 \%$ due to cryopreservation. This decline was explained by the loss of fertility of only one sperm, and only in large-volume conditions, probably due to the delay of use after thawing. $\odot$ Ifremer/Elsevier, Paris
\end{abstract}

\section{Cryopreservation / spermatozoa / insemination / cryobank / sea bass / Dicentrarchus labrax}

Résumé - Cryoconservation du sperme du loup (Dicentrarchus labrax) en conditions expérimentales et application à la production. Un protocole de cryoconservation du sperme mis au point chez le turbot a été appliqué au loup en petit (250 $\mu \mathrm{L})$ et grand volume $(1,5 \mathrm{~mL})$. Dilué dans le milieu de Mounib et congelé par une baisse de température de $-65^{\circ} \mathrm{C} \cdot \mathrm{min}^{-1}$, le sperme a présenté à la décongélation une motilité initiale comparable à celle du témoin, mais une chute de motilité significativement supérieure $(p<0,001, n=10)$ aux temps d'observation ultérieurs. L'insémination de petits volumes ( $2 \mathrm{~mL}$, soient approximativement 2000 ovules) à l'aide d'un nombre limitant de 35000 spermatozoïdes par ovule, a révélé une baisse significative de la fertilité du sperme décongelé ( $p<0,001, n=12$ spermes de mâles différents). L'apport de 70000 ou 200000 spermatozoïdes par ovule dans les mêmes conditions expérimentales a permis de masquer la différence de fertilité entre sperme frais et sperme décongelé. Un plan d'expérience a été réalisé pour étudier l'efficacité de la cryoconservation à l'échelle de la production ou d'une banque de sperme. Des triplicats de 2 et $50 \mathrm{~mL}$ d'ovules (2000 et 50000 ovules respectivement) ont été inséminés à raison de 200000 spermatozoïdes par ovule. L'opération a été renouvelée avec le sperme frais et congelé de cinq mâles différents. Le taux de fécondation à l'aide de sperme décongelé a été inférieur de $23,5 \%$ à celui dû au sperme frais. Cette baisse est expliquée par la perte de fertilité d'un seul sperme et uniquement dans les conditions de grand volume, probablement due au délai d'utilisation du sperme après décongélation. (C) Ifremer/Elsevier, Paris

Cryoconservation / spermatozoïde / insémination / banque de sperme / loup / Dicentrarchus labrax

\footnotetext{
* Corresponding author, e-mail: cfauvel@ifremer.fr
} 


\section{INTRODUCTION}

Cryopreservation of sperm will play a crucial role in the improvement of broodstock management of cultured fish species. Most previous work has dealt with salmonids, carps and tilapias. A few marine species were also studied. The multiple methods tested have led to variable results even within the same species. However, some general trends appear. Cryopreservation decreases sperm fertility. The results are highly variable both between and within methods [3, 23]. Moreover, variations were found among individuals and even between the ejaculates of the same male [17]. Marine fish sperm seems to withstand better cryotreatment [25] probably due to a high cholesterol/phospholipid ratio in sperm membrane [5], initial ATP content and other uncontrolled factors [19].

Recently, a simple cryopreservation protocol for turbot (Psetta maxima) spermatozoa yielded high postthaw motility and fertilisation rate [4]. For this species, the motility and hence the fertility of fresh spermatozoa is high for several minutes after activation [28], probably due to the ability of sperm to regenerate ATP by de novo oxidative respiration [4].

Sea bass sperm is highly concentrated [31], its motility does not vary between males but it may be altered by ageing at the end of the reproductive season [2]. The duration of sperm motility is very short compared to that of turbot so that no fertilisation occurs $30 \mathrm{~s}$ after sperm activation. As in other marine fish, sea bass sperm motility is triggered by a hyperosmotic shock. Lastly, ten times more spermatozoa than in turbot are needed to obtain an optimised fertilisation. In the present paper, the turbot cryopreservation method was extended to sea bass sperm which presents very different biological features. Moreover, since large scale cryopreservation experiments are scarce $[13,30]$ and since such a technique may be very useful for the development of sea bass aquaculture, particular attention was paid to the comparison between laboratory and pre-industrial scales.

\section{MATERIALS AND METHODS}

\subsection{Gamete collection}

This study was carried out on a broodstock of $90 \mathrm{fish}, 20 \%$ of which were hatchery reared. Fish were placed in 2 tanks containing 1.5 to $3 \mathrm{~kg}$ wet weight males and 2 to $5 \mathrm{~kg}$ females. The sex ratio was $2 / 3$ (male/female). The stocking density was $10 \mathrm{~kg} \cdot \mathrm{m}^{-3}$. The flowing rate was $15 \%$ of the tank volume per hour. Sea bass were daily fed ad libitum with pellets and fresh trash-fish was provided once a week. Slocks were subjected to controlled cycles of temperature (minimum-maximum: $13-22^{\circ} \mathrm{C}$ ) and photoperiod (8$16 \mathrm{~h}$ ) with twice-a-week adjustments simulating circ- annual natural conditions. The female spawning season started at the same date plus or minus 5 d over a 5 year period.

When handled, animals were anaesthetised using 100 to $120 \mathrm{~g} \cdot \mathrm{m}^{-3}$ phenoxy ethanol. For each experiment, semen was collected during the spawning period of the females. After drying of the genital area, sperm was collected in 2-mL syringes by a gentle pressure on the testis and sperm ducts. Faeces and urine (checked by colour and viscosity variations) were discarded. Then, sperm samples were stored at $4^{\circ} \mathrm{C}$ on ice, until used. Sperm concentration was determined, after dilution (1:500) in distilled water, by spectrophotometry (Beckman DU600) at a $260 \mathrm{~nm}$ wavelength using the equation $\mathrm{SC}=(0.806 \mathrm{OD}-0.032) 10^{8}$, where $\mathrm{SC}$ and $\mathrm{OD}$ are respectively sperm concentration $\left(\mathrm{spz} \cdot \mathrm{mL}^{-1}\right)$ and optical density.

For egg collection, females were isolated, at $13{ }^{\circ} \mathrm{C}$ in individual tanks $\left(1 \mathrm{~m}^{3}\right)$. Eggs were collected by stripping $72 \mathrm{~h}$ after a single injection of $10 \mu \mathrm{g} \cdot \mathrm{kg}^{-1}$ of D-Trp6 LHRHa (Sigma Chemicals, St Louis, MO, USA). As described in Fauvel et al. [6], the quality of ova was estimated from their morphological features under a dissecting microscope.

\subsection{Development of cryopreservation methods}

The freezing diluent was Mounib's medium complemented with $10 \%$ dimethyl sulfoxyde and $10 \mathrm{mg} \cdot \mathrm{mL}^{-1}$ bovine serum albumin [4] (table I). Sperm was first diluted to $1 / 3(\mathrm{v} / \mathrm{v})$ in freezing diluent, and was quickly shaken and immediately placed in straws or cryovials. The dilution was not allowed to equilibrate but was directly subjected to freezing protocols. Two cooling protocols were used taking into account the different volumes of sperm to be stored. Small volumes were frozen in $250-\mu \mathrm{L}$ straws according to the method developed for turbot by Dreanno et al. [4]. Straws (I.M.V., France) were placed for $15 \mathrm{~min}$ on a tray in nitrogen vapour, $6.5 \mathrm{~cm}$ above the liquid nitrogen surface. Larger samples were poured into $1.5-\mathrm{mL}$ cryovials (Nalgene). The cooling rate was assessed by placing a thermocouple in empty straws or cryovials; temperatures were noted every $15 \mathrm{~s}$ for $1 \mathrm{~min}$, every $30 \mathrm{~s}$ for 2 min and every minute until 16 min passed. The procedure was repeated three times for each freezing protocol. Finally, in order to obtain a cooling rate similar to that obtained in small volume straws, cryovials were directly immersed for $15 \mathrm{~s}$ into liquid nitrogen, then were laid on a tray $2 \mathrm{~cm}$ above liquid nitrogen for 15 min before being dropped back into liquid nitrogen. The variations of temperature of sperm during cooling were assessed by the same procedure with the thermocouple placed in sperm samples; straws were thawed in a waterbath at $35^{\circ} \mathrm{C}$ for $5 \mathrm{~s}$, whereas cryovials were thawed under agitation, in a $50^{\circ} \mathrm{C}$ waterbath for $1 \mathrm{~min}$. 
Table I. Composition of extenders for sea bass sperm*.

\begin{tabular}{llll}
\hline Components & Mounib's modified medium & Non-activating medium & Activating medium \\
\hline $\mathrm{NaCl}\left(\mathrm{mg} \cdot \mathrm{mL}^{-1}\right)$ & - & 3.5 & - \\
$\mathrm{KCl}\left(\mathrm{mg} \cdot \mathrm{mL}^{-1}\right)$ & - & 0.11 & - \\
$\mathrm{MgCl}\left(\mathrm{mg} \cdot \mathrm{mL}^{-1}\right)$ & - & 1.23 & - \\
$\mathrm{CaCl}\left(\mathrm{mg} \cdot \mathrm{mL}^{-1}\right)$ & - & 0.39 & - \\
$\mathrm{NaHCO}\left(\mathrm{mg} \cdot \mathrm{mL}^{-1}\right)$ & 10.01 & 1.68 & - \\
$\mathrm{KHCO}\left(\mathrm{mg} \cdot \mathrm{mL}^{-1}\right)$ & 1.99 & - & - \\
Reduced gluthatione $\left(\mathrm{mg} \cdot \mathrm{mL}^{-1}\right)$ & - & - & - \\
Glucose $\left(\mathrm{mg} \cdot \mathrm{mL}^{-1}\right)$ & 42.78 & 0.08 & - \\
Sucrose $\left(\mathrm{mg} \cdot \mathrm{mL}^{-1}\right)$ & 10 & - & 10 \\
BSA $\left(\mathrm{mg} \cdot \mathrm{mL}^{-1}\right)$ & Distilled water & 10 & Scawater $\left(\right.$ salinity: $\left.38 \mathrm{~g} \cdot \mathrm{L}^{-1}\right)$ \\
Diluent & 7.8 & distilled water & 8.2 \\
pH & 310 & 7.7 & 160 \\
Osmolality $\left(\mathrm{mOsm}^{\mathrm{k}} \cdot \mathrm{kg}^{-1}\right)$ & 310 & 160 \\
\hline
\end{tabular}

* Chemicals from Sigma Chemical Co., St Louis, MO, USA.

\subsection{Motility assessment}

Because frozen-thawed sperm were first diluted to $1 / 3$ $(\mathrm{v} / \mathrm{v})$ in freezing diluent, the motility of samples was quantified using a direct dilution method: $1 \mu \mathrm{L}$ of diluted semen was added to $300 \mu \mathrm{L}$ of an activating medium (table $I$ ) so that the final dilution was 1/900. For fresh sperm, freezing diluent was replaced by a non-activating medium (table $I$ ). The percentage of motile spermatozoa was assessed by two observers, every $10 \mathrm{~s}$ after activation, using an arbitrary scale of 6 classes where 0 represented no motile cells, 1 : $1-20 \%, 2: 20-40 \%, 3: 40-60 \%, 4: 60-80 \%$ and 5 : $80-100 \%$ of spermatozoa showing progressive movement. The flagellar beat frequency and the velocity of fresh and frozen-thawed spermatozoa were assessed according to Dreanno et al. [4], using respectively 14 sperm samples from 3 males and 30 tracks of spermatozoa of each sample, in either fresh or frozenthawed status, collected from 3 males. All the observations were done at room temperature $\left(18^{\circ} \mathrm{C}\right)$.

\subsection{Insemination}

The fertilising ability of fresh and frozen-thawed small volumes of sperm collected from 6 males was compared using the following experimental protocol. Fresh sperm were prepared by direct dilution to $1 / 10$ ( $/ / v)$ in non-activating medium. For cryopreservation, sperm were diluted to $1 / 3(\mathrm{v} / \mathrm{v})$ in Mounib's medium before freezing and $1 / 3.3(\mathrm{v} / \mathrm{v})$ in non-activating medium at thawing (resulting dilution of thawed sperm being similar to that of fresh sperm). Triplicate 2-mL batches of ova were inseminated using adjusted volumes of diluted sperm (from 10 to $85 \mu \mathrm{L}$ ) so as to obtain three different spermatozoa:egg ratios $\left(35 \cdot 10^{3}\right.$, $70 \cdot 10^{3}$ and $200 \cdot 10^{3}$, respectively considered as a discriminating ratio, an optimum ratio and a secure ratio). Frozen sperm samples were thawed and diluted individually just before insemination in order to avoid a possible decrease of fertility due to the post-thaw

Aquat. Living Resour. 11 (6) (1998) delay. Fertilisation was triggered by the addition of $1 \mathrm{~mL}$ seawater $\left(38 \mathrm{~g} \cdot \mathrm{L}^{-1} ; 13^{\circ} \mathrm{C}\right)$.

The fertilising capacity of 'small' $(200 \mu \mathrm{L})$ and 'large' $(1.5 \mathrm{~mL})$ volumes of frozen-thawed sperm was compared. Five individual sperm samples were cryopreserved using the following two freezing protocols. Fresh and frozen-thawed 'small' sperm samples were laid on triplicate 2-mL batches of eggs, following the insemination protocol described above. 'Large' volume frozen sperm samples were thawed all together; triplicate $50-\mathrm{mL}$ batches of eggs were inseminated adding either fresh (diluted to $1 / 3$ with non-activating medium) or frozen-thawed (diluted to $1 / 3$ with Mounib's medium) sperm (final dilution 1/3 for both) and $25 \mathrm{~mL}$ seawater. Sperm sample volume was individually adjusted in order to provide a constant $200 \cdot 10^{3}$ sperm:egg ratio.

\subsection{Statistical treatment}

Data are expressed as mean $\pm S E$. Motility classes of fresh and frozen-thawed sperm were compared using a signed rank test (Wilcoxon test) for each post-activation time. The slopes of linearised decrease with time of the flagellum beat frequency of fresh and frozenthawed sperm were compared using a covariance analysis (ANCOVA). After angular transformation, the comparison of the mean fertilisation rates was performed by a two-way ANOVA with sperm/egg ratio and sperm status as factors and individual males as blocks. When differences were significant, a StudentNewman-Keuls a posteriori test was used for comparison. In order to evaluate the individual response of the different sperm to the different cryopreservation protocols, mean fertilisation rates were compared using three-way ANOVA in which individual semen were taken as a factor of variation. The Student-NewmanKeuls test was applied within groups in which no significant interaction was found. The statistical analysis were computed using Sigmastat software (SPSS Inc., Chicago, IL, USA). 


\section{RESULTS}

\subsection{Temperature curve at freezing}

The deposition of $150-\mu \mathrm{L}$ opened straws at $6.5 \mathrm{~cm}$ from the surface of liquid nitrogen for $15 \mathrm{~min}$ resulted in a linear decrease of temperature from 22 to $-60.5^{\circ} \mathrm{C}$ $\left(r^{2}=0.97\right)$ in straws at a cooling rate of $64.9^{\circ} \mathrm{C} \cdot \mathrm{min}^{-1}$ (figure 1). A quite similar temperature profile was obtained with the protocol designed for $1.5-\mathrm{mL}$ empty cryovials. The cooling rate was $61.0^{\circ} \mathrm{C} \cdot \mathrm{min}^{-1}$. The temperature decrease stabilised at $-95^{\circ} \mathrm{C}$ after $12 \mathrm{~min}$. When the thermocouple was placed into containers with diluted sperm, the temperature profiles were modified due to cristallisation. The seeding point occurred at $10 \mathrm{~s} /-5^{\circ} \mathrm{C}$ in straw and $12 \mathrm{~s} /-11^{\circ} \mathrm{C}$ in cryovial and the temperature surges were respectively up to $-0.9^{\circ} \mathrm{C}$ and $-2{ }^{\circ} \mathrm{C}$. The temperature decrease in cryotube was slower but more regular than in straw so that the variations after 3 min $\left(-60^{\circ} \mathrm{C}\right)$ were similar for the different containers. The decrease slowed down to zero at $-93{ }^{\circ} \mathrm{C}$ and then the temperature remained stable for $5 \mathrm{~min}$. The temperature dropped abruptly to $-193^{\circ} \mathrm{C}$ when straws or vials were dropped into liquid nitrogen.

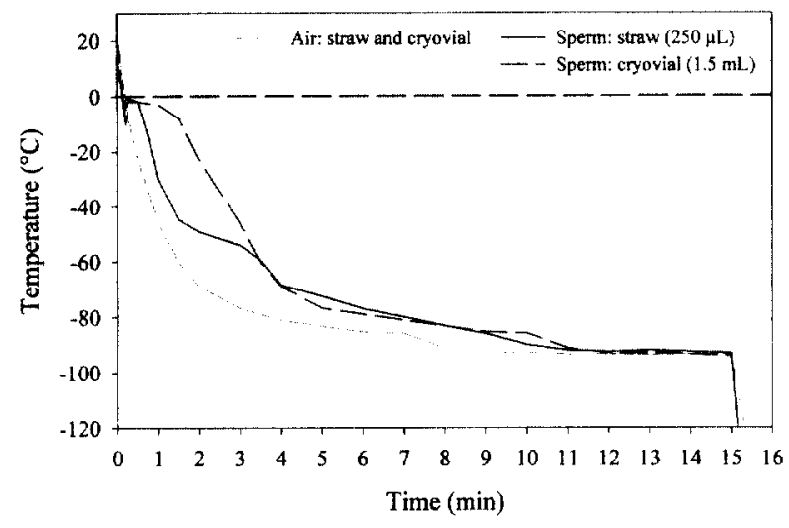

Figure 1. Temperature decays recorded for the different freezing protocols.

\subsection{Effect of freezing-thawing on sperm motility}

No significant difference was found between fresh and frozen-thawed sperm motility classes $10 \mathrm{~s}$ after activation (figure 2). However, frozen-thawed sperm motility was significantly lower $(P<0.001)$ the longer the delay after activation. In any case, the total motility duration was less than $40 \mathrm{~s}$ for frozen-thawed sperm while fresh sperm might present motile cells for $50 \mathrm{~s}$.

The regressions of the flagellar beat frequencies (after $\log$ transformation) of fresh and frozen-thawed sperms with time between 5 and $35 \mathrm{~s}$ after activation, obeyed the following equations respectively: $\mathrm{y}=-0.0507 \mathrm{x}+4.41, r^{2}=0.59 ; P<0.001$ and $\mathrm{y}=-0.0599 \mathrm{x}+4.49 ; r^{2}=0.77 ; P<0.001$ (figure 3). Neither slopes nor origins were significantly different.
Therefore, the decrease of fresh and frozen-thawed sperm beat frequency can be represented by a common linear regression with -0.0555 as a slope and 4.46 as an origin.

Fresh sperm straight and curvilinear velocities decreased from 110 to $20 \mu \mathrm{m} \cdot \mathrm{s}^{-1}$ between 5 and $45 \mathrm{~s}$ after activation, respectively (figure 4). After cryopreservation, both initial velocities were significantly lower than those of fresh sperm, whereas they were no longer different $30 \mathrm{~s}$ after activation. A significant difference was observed again for curvilinear velocity at 40 and $45 \mathrm{~s}$.

\subsection{Effect of freezing-thawing on fertilisation for different sperm availability per egg}

The two-way ANOVA did not reveal any significant differences in mean fertilisation rates due to the levels of sperm to egg ratio and sperm status (fresh/thawed; figure 5). However, there was a significant interaction between these factors $(P<0.01)$. The comparison of the fertilisation rates resulting from fresh and thawed sperm for the different sperm:egg ratios by one-way ANOVA revealed that only insemination with $35 \cdot 10^{3}$ thawed spermatozoa per egg yielded a significantly lower fertilisation rate $(P<0.01)$ than fresh sperm at the same concentration and fresh and thawed sperm at higher sperm:egg ratios.

\subsection{Effect of freezing-thawing on fertilisation in different scale inseminations with sperm in excess}

The comparison of mean fertilisation rate by twoway ANOVA with freezing and insemination volume as factors, revealed no significant difference due to the scale of the insemination procedure but it showed that frozen sperm gave significantly lower fertilisation rate than fresh sperm $(P<0.05 ;$ table II). There was no significant interaction between factors.

The comparison of fertilisation rate by three-way ANOVA with individual fish semen, sperm treatment and scale of insemination as factors, showed a signifi-

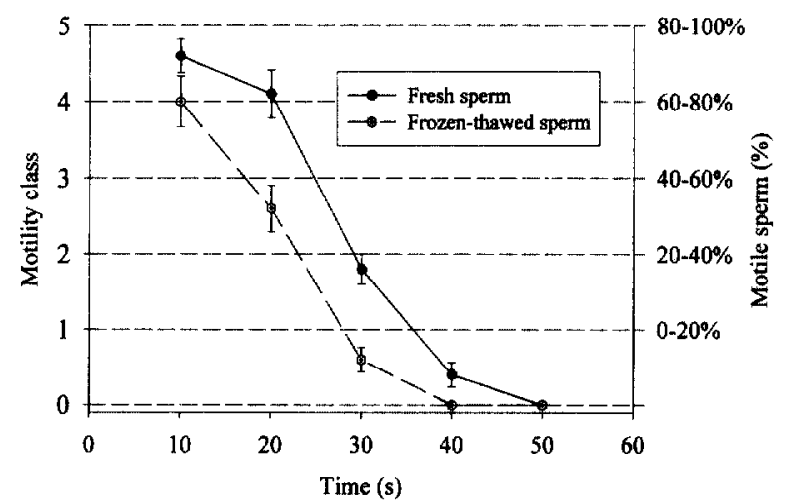

Figure 2. Changes in fresh and frozen-thawed sperm motility with time $(n=10)$. 
Figure 3. Plot of fresh and frozen spermatozoa beat frequencies at different times after activation and for 3 different male semens. The different symbol shapes refer to different males.
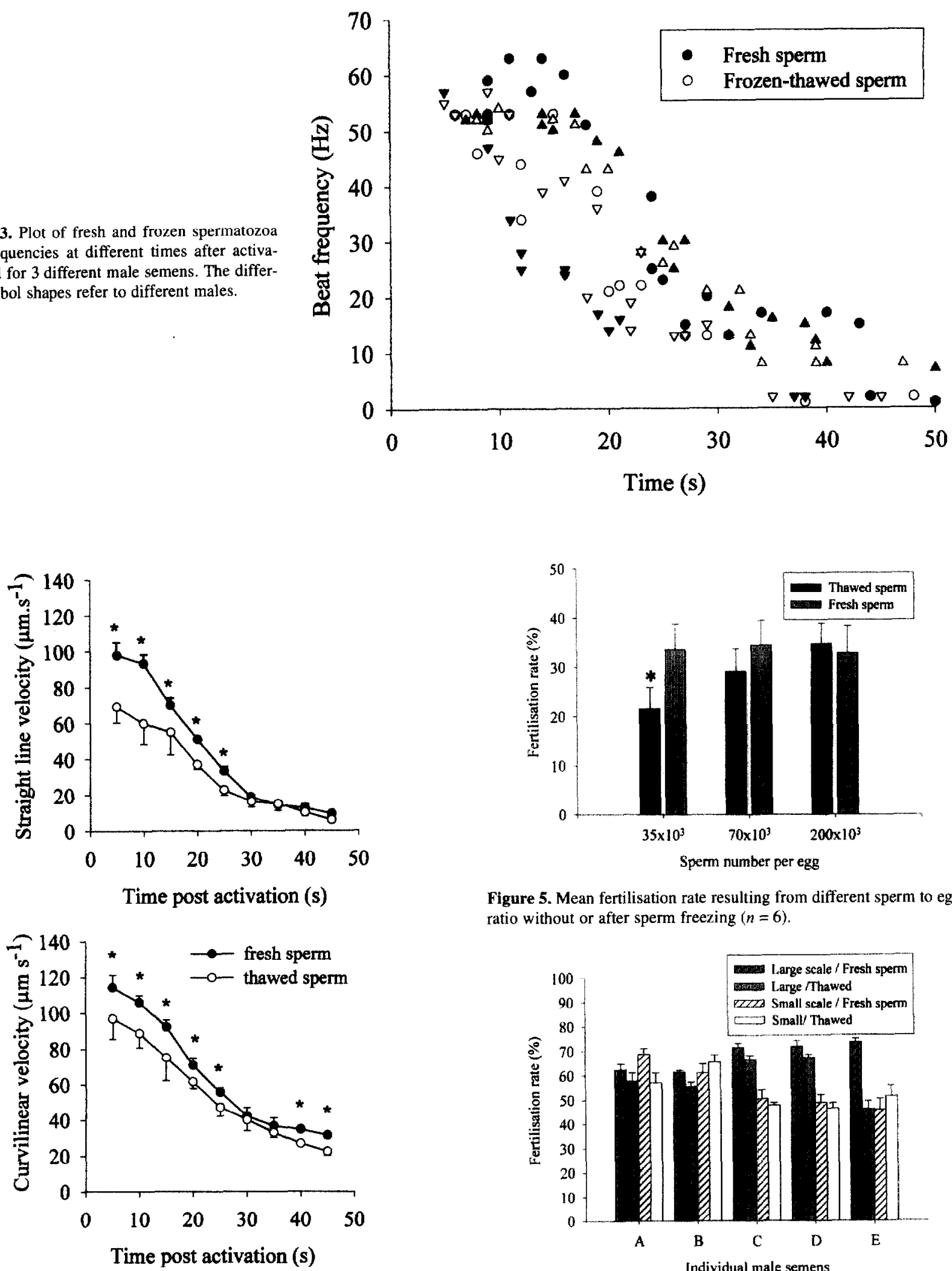

Figure 4. Changes in fresh and frozen-thawed spermatozoa motility with time after activation. Stars show times for which a significant difference was found between fresh and frozen sperm velocities $(n=90)$.

Figure 5. Mean fertilisation rate resulting from different sperm to egg ratio without or after sperm freezing $(n=6)$.

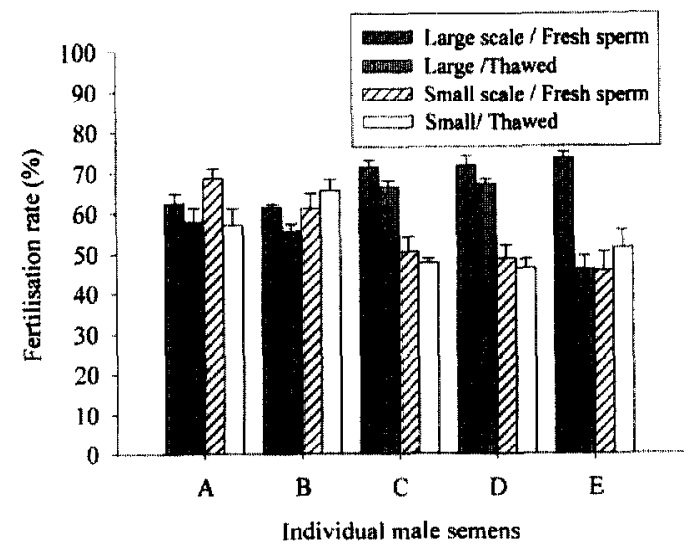

Figure 6. Mean individual fertilisation capacity of fresh and thawed semens subjected to two different scale freezing and insemination protocoles $(n=3)$. The semens were individually collected from five different males identified by capital letters 
Table II. Combined effects of cryopreservation and upgrading on the sperm's ability to fertilise.

\begin{tabular}{|c|c|c|c|}
\hline \multirow[t]{2}{*}{$\mathrm{Egg} /($ sperm/ov $) /$ seawater } & \multicolumn{2}{|c|}{$\begin{array}{l}\text { Fertilisation rate } \pm \mathrm{SD} \\
\qquad(\%)\end{array}$} & \multirow[t]{2}{*}{$\begin{array}{l}\text { Loss due to freezing-thawing } \\
\text { (\%) }\end{array}$} \\
\hline & Fresh sperm & Frozen sperm & \\
\hline $\begin{array}{c}2 \mathrm{~mL} / 200 \cdot 10^{3} / 1 \mathrm{~mL} \\
50 \mathrm{~mL} / 200 \cdot 10^{3} / 25 \mathrm{~mL}\end{array}$ & $\begin{array}{l}69.7 \pm 0.7 \\
80.9 \pm 0.7\end{array}$ & $\begin{array}{l}62.4 \pm 0.7 \\
68.8 \pm 0.7\end{array}$ & $\begin{array}{l}10.5 \\
23.5\end{array}$ \\
\hline
\end{tabular}

cant interaction between the three factors $(P<0.001$; figure 6). The Student-Newman-Keuls test revealed a difference of fertilisation rate between fresh and frozen sperm solely in the combination: 'male E/large volume' and an increase due to scaling up in males $C$ and $D$.

\section{DISCUSSION}

In the present work, sea bass spermatozoa was successfully frozen, following the cryopreservation method developed in turbot [4]. This method used Mounib's extender which has been used for spermatozoa cryopreservation since 1968 in plaice (Pleuronectes platessa) [22], Atlantic salmon (Salmo salar) and cod (Gadus morhua) [18]. Proteins were added to the extender in order to prevent damages to the plasma membrane as suggested by Scott and Baynes [25] and Harvey et al. $[9,10]$. Adding egg yolk to Mounib's extender improved the fertilising capacity of frozenthawed spermatozoa of rainbow trout (Oncorhynchus mykiss) [12]. Dimethyl sulfoxyde, used as a permeating agent in many other fish species [26], was also efficient for freezing sea bass sperm. Semen was diluted to $1 / 3(\mathrm{v} / \mathrm{v})$ before freezing since lower predilution rates may decrease post-thaw fertility in salmonids [11]. However, the predilution was not found to affect tilapia sperm survival [24]. In the present work, whatever the sperm volume treated and the container used, the cooling rate applied to samples was comprised between 60 and $65^{\circ} \mathrm{C} \cdot \mathrm{min}^{-1}$. The resulting temperature curve in sperm samples showed a difference between the volumes subjected to the protocols. The decrease was similar until the seeding point, but the cristallisation was longer in large samples so that the latency before further cooling was longer. This cooling rate is reported to be important for freezing success; however, it ranges from -1 to $-35^{\circ} \mathrm{C} \cdot \mathrm{min}^{-}$for rainbow trout $[15,25]$, to -20 to $-150^{\circ} \mathrm{C} \cdot \mathrm{min}^{-1}$ for black grouper (Epinephelus malabricus) [7] and yellowfin seabream (Acanthopagrus latus) [8], and -20 to $-80^{\circ} \mathrm{C} \cdot \mathrm{min}^{-1}$ for mammalian sperms [30]. Some authors recommend having an equilibration time after predilution, allowing dimethyl sulfoxyde to penetrate the spermatozoa before freezing $[21,27]$. However, such a delay was not observed to improve cryopreservation success in trout $[11,26]$. Sea bass sperm was not allowed to equilibrate with freezing medium in the present work.

Sea bass sperm motility was affected by the freezing-thawing procedure: although not altered for the first time point, the proportion of motile cells (motility class) decreased faster with time in thawed sperm samples than in fresh ones. Furthermore, the duration of movement and velocities were also affected. Similar modifications of motility parameters of frozen-thawed spermatozoa were reported in rainbow trout [11] and amago salmon (Oncorhynchus masou ishikawae) [20]. In turbot, the percentage of motile cells was significantly altered by the cryopreservation process, but neither velocity nor movement duration were decreased [4]. However, as in Siberian sturgeon (Acipenser baeri) [29], sea bass sperm flagellar beat frequency was not affected by the cryopreservation process. The decrease of straight line velocity of frozen-thawed spermatozoa could be explained by a modification of trajectories as is the case in rainbow trout [11].

At laboratory scale ( $2-\mathrm{mL}$ egg batches), the insemination with 35000 spermatozoa per egg was sensitive to variations of sperm fertility. Under these conditions, the fertilising capacity of frozen-thawed sea bass spermatozoa was decreased compared to fresh sperm. This can reflect the change in motility parameters observed after the freezing process. However, this fertility decay can be compensated by providing a higher spermatozoa to egg ratio for which no significant decrease was noted. As a consequence, the optimum ratio of $70000 \mathrm{spz} / \mathrm{egg}$ does not theoretically need to be increased for inseminations using frozen-thawed spermatozoa. On the contrary, a five- to ten-fold higher ratio of frozen spermatozoa is necessary in salmonids [11]. Higher amounts of frozen spermatozoa are also required in yellowfin sea bream (Acanthopagrus latus) [8] and in turbot [4].

Large scale cryopreservation protocols for production purposes have been tested [1, 14]. In rainbow trout [30] and European catfish (Silurus glanis) [13], sperm have been successfully frozen in large straws (4.5$5.0 \mathrm{~mL}$ ). In sea bass, the upgrading from $250-\mu \mathrm{L}$ straws to 1.5-mL cryovials was successfully performed although sample temperature decay was altered. The upscaling from $2-\mathrm{mL}$ to $50-\mathrm{mL}$ insemination batches of eggs using respectively straw and cryovial sperm with $200 \cdot 10^{3}$ spermatozoa per egg, did not modify the resulting fertilisation rates. However, the freezing process significantly appeared to affect fertilisation when compared to that of fresh sperm. A more discriminating analysis using individual semen as a factor of variation showed that only one large scale sample of semen out of five presented a lower fertility at thawing. 
Since no significant difference was observed in small scale experiment for this particular semen and since the sperm was the last to be used after common thawing of five sperms, the failure may be due to an excessive delay between thawing and insemination. Nevertheless, the failure of one or more sperm may be due to the heterogeneity of response to cryopreservation between males [16] and between ejaculates of a given male [17].

In conclusion, Mounib's freezing diluent, the initial dilution and the cooling rate defined for turbot sperm freezing revealed to be adequate for sea bass sperm both at experimental and production pilot scale. In addition, $1.5-\mathrm{mL}$ cryotubes can be successfully used as sperm freezing containers. Such tubes are particularly useful for sea bass cryobank purposes since the average sperm concentration is about $50 \cdot 10^{9}$ spermatozoa/ $\mathrm{mL}$ in sea bass, the fertilisation of $100000 \mathrm{eggs,}$ approximately contained in $100-\mathrm{mL}$ spawn volume, by frozen-thawed sperm will require the use of $400 \mu \mathrm{L}$ native sperm, i.e. $1.2 \mathrm{~mL}$ diluted frozen sperm.

For mass production purposes, it will be more secure to blend different sperms either before or after cryoconservation in order to limit the effect of heterogeneity as recommended by Legendre and Billard [12] and Maisse [16]. In case of specific individual crosses needed for genetic designs, it should be useful to test each sperm cryopreservation ability by using laboratory-scale inseminations.

\section{Acknowledgements}

The authors wish to thank Loï Quemener for his helpful comments and involvement in statistical analysis and Marie Joseph Debos for her help with the bibliography.

\section{REFERENCES}

[1] Alderson R., McNeil A.J., Preliminary investigations of cryopreservation of milt of Atlantic salmon (Salmo salar) and its application to commercial farming, Aquaculture 43 (1984) 351-354.

[2] Billard R., La conservation des garnètes et l'insémination artificielle chez le bar et la daurade, in: Barnabé $\mathrm{G}$., Billard R. (Eds.), L'aquaculture du bar et des sparidés, Inra, Paris, 1984, pp. 95-116.

[3] Billard R., Cosson J., Crim L.W., Suquet M., Sperm physiology and quality, in: Bromage N.R., Roberts R.J. (Eds.), Broodstock management and egg and larval quality, Blackwell Science, Oxford, 1995, pp. 25-52.

[4] Dreanno C., Suquet M., Quemener L., Cosson J, Fierville F., Normant Y., Billard R., Cryopreservation of turbot (Scophthalmus maximus) spermatozoa, Theriogenology 48 (1997) 589-603.

[5] Drokin S.I., Phospholipid distribution and fatty acid composition of phosphatidylcholine and phosphatidylethanolamine in sperm of some freshwater and marine species of fish, Aquat. Living Resour. 6 (1993) 49-56.

[6] Fauvel C., Omnes M.H., Suquet M., Normant Y., Reliable assessment of overripening in turbot (Scophthalmus maximus) by a simple $\mathrm{pH}$ measurement, Aquaculture 117 (1992) 107-113.

[7] Gwo J.C., Cryopreservation of black grouper (Epinephelus malabaricus) spermatozoa. Theriogenology 39 (1993) 1331-1342.

[8] Gwo J.C., Cryopreservation of yellowfin seabream (Acanthopagrus latus) spermatozoa (Teleost, Perciforms, Sparidae), Theriogenology 41 (1994) 989-1004.

[9] Harvey B., Cryopreservation of Sarotherodon mossam. bicus spermatozoa, Aquaculture 32 (1983) 313-320.

Aquat. Living Resour. 11 (6) (1998)
[10] Harvey B., Kelley R.N., Ashwood-Smith M.J., Cryopreservation of zebrafish spermatozoa using methanol, Can. J. Zool. 60 (1982) 1867-1870.

[11] Lahnsteiner F., Patzner R.A., Weismann T., Semen cryopreservation of salmonid fishes: influence of handling parameters on the postthaw fertilization rate, Aquac. Res. 27 (1996) 659-671.

[12] Legendre M., Billard R., Cryopreservation of rainbow trout sperm by deep freezing, Reprod. Nutr. Dev, 20 (1980) 1859-1868.

[13] Linhart O., Billard R., Proteau J.P., Cryopreservation of European catfish (Silurus glanis L.) spermatozoa, Aquaculture 115 (1993) 3347-3359.

[14] Lubzens E., Daube N., Pekarsky I., Magnus Y., Cohen A., Yusefovich F., Feigin P., Carp (Cyprinus carpio L.) spermatozoa cryobanks strategies in research and application, Aquaculture 155 (1997) 13-30.

[15] McAndrew B.J., Rana K.J., Penman D.J., Conservation and preservation of genetic variation in aquatic organisms, in: Muir J.F., Roberts R.J. (Eds.), Recent Advances in Aquaculture, vol. IV, Blackwell Science, Oxford, 1993, pp. 295-336.

[16] Maisse G., Le sperme des salmonidés : le point sur les connaissances applications à la salmoniculture, Inra Prod. Anim. 3 (1990) 223-228.

[17] Maisse G., Cryopreservation of fish semen: a review, in: Proc. Refrigeration and Aquaculture, Eur. Aquac. Soc., 1996, pp. 443-466.

[18] Mounib M.S., Cryogenic preservation of fish and mammalian spermatozoa, J. Reprod. Fert. 53 (1978) 13-18.

[19] Ogier de Baulny B., Cryoconservation du sperme de poissons, évaluation des dommages cellulaires, amélioration de la technique de congélation, perméabilité membranaire aux cryoprotecteurs, thèse, Écule nationale supérieure agronomique de Rennes, 1997, 129 p. 
[20] Otha H., Shimma H., Hirose K., Relationship between fertility of cryopreserved spermatozoa of the amago salmon Onchorhynchus masou ishikawae, Fish Sci. 61 (1995) 886-887.

[21] Ott A.G., Horton H.F., Fertilization of chinook and coho salmon eggs with cryopreserved sperm, J. Fish. Res. Board Can. 28 (1971) 745-748.

[22] Pullin R.S.W., The storage of plaice (Pleuronectes platessa) sperm at low temperature, Aquaculture 1 (1972) 279-283.

[23] Rana K.J., Cryopreservation of aquatic ganetes and embryos: recent advances and applications, in: Goetz F.W., Thomas P. (Eds.), Proc. 5th Int. Symp. Reproductive Physiology of Fish, Austin, Texas, USA, 2-8 July 1995 , pp. 85-89.

[24] Rana K.J., McAndrew B.J., The viability of cryopreserved tilapia spermatozoa, Aquaculture 76 (1989) 335-345.

[25] Scott A.P., Baynes S.M., A review of the biology, handling and storage of salmonid spermatozoa, J. Fish Biol. 17 (1980) 707-739.

[26] Stoss J., Holz W., Cryopreservation of rainbow trout (Salmo gairdneri) sperm. IV, The effect of DMSO concentration and equilibration time on sperm survival, sucrose and $\mathrm{KCl}$ as extender components and the osmolality of the thawing solution, Aquaculture 32 (1983) 321-330.

[27] Steyn G.J., The effect of freezing rate on the survival of cryopreserved sharptooth catfish (Clarias gariepinus) sperm, Cryobiology 30 (1993) 581-590.

[28] Suquet M., Billard R., Cosson J., Normant Y., Fauvel C., Artificial insemination in turbot (Scophthaimus maximus): determination of the optimal sperm to egg ratio and time of gamete contact, Aquaculture 133 (1995) 83-90.

[29] Tsvetkova L.I., Cosson J., Linhart O., Billard R., Motility and fertilizing capacity of fresh and frozen-thawed spermatozoa in sturgeons Acipenser baeri and $A$. ruthenus, J. Appl. Ichthyol. 12 (1996) 107-112.

[30] Wheeler P.A., Thorgaard G.H., Cryopreservation of rainbow trout semen in large straws, Aquaculture 93 (1991) 95-100.

[31] Zohar Y., Billard R., Weil C., La reproduction de la daurade (Sparus aurata) et du bar (Dicentrarchus labrax) : Connaissance du cycle sexuel et contrôle de la gamétogenèse et de la ponte, in: Barnabé G., Billard R. (Eds.), L'aquaculture du bar et des sparidés, Inra, Paris, 1984, pp. 3-24. 